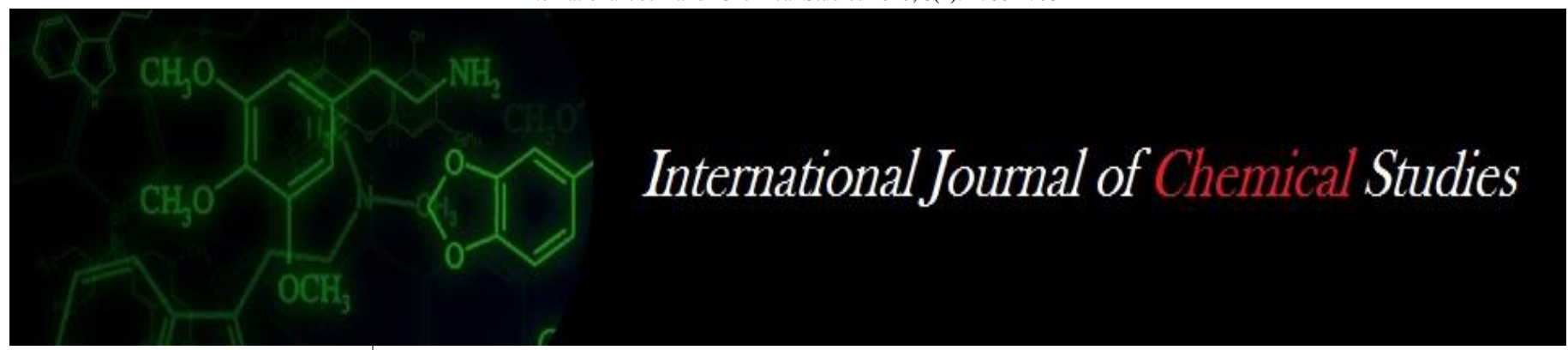

P-ISSN: 2349-8528

E-ISSN: 2321-4902

www.chemijournal.com

IJCS 2020; 8(4): 1700-1708

(C) 2020 IJCS

Received: 22-05-2020

Accepted: 24-06-2020

Anirban Sil

Division of Agricultural

Chemicals, Indian Agricultural

Research Institute, New Delhi,

India

Debrup Ghosh

Division of Soil Science and

Agricultural Chemistry, Indian

Agricultural Research Institute,

New Delhi, India

\section{Mainak Barman}

Department of Plant Breeding and Genetics, Dr. Rajendra

Prasad Central Agricultural

University, Pusa, Bihar, India

\section{Koushik Bhattacharyya}

Department of Soil Science,

Chaudhary Charan Singh

Haryana Agricultural

University, Hisar, Haryana,

India

Sujit Das

Division of Soil Science and Agricultural Chemistry, Indian Agricultural Research Institute, New Delhi, India

\section{Biswajit Horijan}

Division of Agricultural

Chemicals, Indian Agricultural Research Institute, New Delhi, India

\section{Sandip Lohara}

Department of Soil Science and Agricultural Chemistry, Uttar Banga Krishi Viswavidyalaya, Coochbehar, West Bengal, India

Corresponding Author: Anirban Sil

Division of Agricultural Chemicals, Indian Agricultural Research Institute, New Delhi, India

\section{Strategies for mitigation of polychlorinated biphenyls (PCBs): A review}

\author{
Anirban Sil, Debrup Ghosh, Mainak Barman, Koushik Bhattacharyya, \\ Sujit Das, Biswajit Horijan and Sandip Lohara
}

DOI: https://doi.org/10.22271/chemi.2020.v8.i4q.9857

\begin{abstract}
Polychlorinated Biphenyls or PCBs belong to a broad family of chlorinated hydrocarbons and find use across industrial and commercial applications including hydraulic and electrical equipments, plastics, paints, rubber products, dyes, pigments and carbonless copy paper etc. PCB residues persist in the ecosystem and bioaccumulate in food chain due to their persistent nature and resistance against natural breakdown agents. Global case studies suggest widespread contamination of the toxicant. So it becomes the need of an hour to remove polychlorinated biphenyls entirely from the environment. Stepwise, physical, chemical and ecological remediation strategies have been applied but some lacuna in efficient mitigation was felt by various researchers in each of the methods. Therefore, combination of multiple technologies have been suggested. The current review provides the detailed descriptions on the different physical and chemical methods used for removal of PCBs including incineration, natural attenuation, supercritical water oxidation, ultrasonic radiation, bimetallic systems, nZVI, etc as well as the combination of multi techniques that have been used till date e.g. nZVI with metal combo and bimetallic metal combination etc. It also depicts the future prospects and acceptability of these methods for removal of the polychlorinated biphenyls from the ecosystem to help us achieve a green sustainable world.
\end{abstract}

Keywords: Remediation, polychlorinated biphenyls, incineration, multi technologies

\section{Introduction}

Polychlorinated biphenyls (PCBs) are the member of chlorinated aromatic hydrocarbons, which have been started using for industrial purposes since the year 1929 when Monsanto in USA had taken initiatives for manufacturing of PCBs under trade name Aroclors. The physicochemical properties(electric insulation, thermal and chemical stability etc) of PCBs makes them eligible for a broad spectrum of applications particularly in coolants, paints, floor finishing, carbonless copy paper makings, electrical transformers etc. They have been classified into Aroclors (Aroclor 1100 and 1200 series) and Congeners. Approximately 209 congeners are there as named by IUPAC according to the no of chlorine atom substitution in the biphenyl rings. Highly chlorinated congeners usually possess high octanol-water partition coefficients $\left(\mathrm{K}_{\mathrm{ow}}\right)$ and therefore often found in organic matter especially in soils and sediments. Moreover, widespread contamination is the result of partitioning of PCBs between aquatic and solid phase, present in multiple compartments due to the hydrophobicity and vapor pressure of PCBs. When PCBs are released into the environment at once, they could bioaccumulate within the food chain, due to their high affinity for organic materials. PCBs have been considered as persistent organic pollutants (POPs) under Stockholm Convention having high toxicity and undesirable effects on the ecosystem ${ }^{[1]}$. Furthermore, they have been found in different body tissues, blood, breast milk and liver, mainly due to consumption of meat, fish, and dairy products ${ }^{[2]}$. Consequentially, they have been associated with chronic effects in humans including immune system damage, decreased pulmonary function, bronchitis, and hormonal interferences leading to carcinogenicity ${ }^{[3]}$. In US and many other countries, different physical, chemical, combined remediation approaches have been established for complete elimination of PCBs but most of the solutions are pretty disruptive, unsustainable and they aggravate transfer of PCBs to various sections of the environment, rather than ridding them ${ }^{[4]}$.Therefore the current review aims at the effectiveness of the prevailing physical and chemical approaches for mitigating PCBs as well as their future perspectives. 


\section{PCB Contamination Scenario}

PCBs have different sources of exposure into the environment such as by evaporation/volatilization of paints, plastics and coatings, downright leakages into sewers and streams, dumping in non-secured landfills followed by other disposal techniques like ocean dumping etc. This leads to contamination of various matrices of water, soil, air and biota. Despite stringent regulations, few PCBs are dumped illegally either by ignorance or by negligence. Approximately, $1 / 3^{\text {rd }}$ of total PCBs manufactured in United States (US) have already entered into the environment ${ }^{[5]}$ and this further continue to rise via dumping of aged electrical appliances like transformers, capacitors etc. Due to the hydrophobicity and persistent nature of PCBs, they have been detected in soil, sediments, air, milk, wildlife, water, fish, plants, human adipose tissues and blood samples at significant concentrations since the year $1966^{[6]}$. More surprisingly, residues of PCBs have been detected in the snow deposits in Antarctic where no industrial activity was reported ${ }^{[7]}$. This contamination leads to the adverse health effects both for human and biota. PCBs are considered as carcinogenic to human by the National Toxicology Program (NTP) and International Agency for Research on Cancer (IARC). Starting from endocrine disrupting effects, PCBs hamper neuron developments and reproductive normalities in human. Besides human, every component of the ecosystem e.g. birds, aquatic animals etc have been identified with higher quantity of PCBs.

\section{Remediation strategies}

Mitigation of this cumbersome PCB pandemics is one of major issues that plagued the researchers for decades. Apart from traditional technologies, some of the multi technologies have been mentioned in various literatures. A bunch of physicochemical approaches for removal of PCBs have been mentioned in this section.

\section{Traditional Technologies:}

A bunch of conventional methods have been tried for mitigating PCBs like physical approaches, thermal incineration, photolysis, adsorption on activated carbon etc.

\section{Incineration}

Conventionally, thermal destruction is a widely used remediation approach in which $\mathrm{PCB}$ react with oxygen at a very high temperature of $850^{\circ}-1350{ }^{\circ} \mathrm{C}$ to form water, $\mathrm{CO} 2$ and $\mathrm{HCl}$ in an incinerator. However, during fire or incineration, more toxic derivatives $\mathrm{PCDD} / \mathrm{Fs}$ may be produced as PCBs are the precursors of PCDD/Fs ${ }^{[8]}$. Usually, this formation takes place during cooling of gases after incineration. The rate of this by products formation depends on gas temperature, existence of chlorine and presence of a catalyst. Moreover, some modern incinerators are there which can be able to withstand higher temperatures and provides dioxin removal facility that further leads to removal of problems of dangerous emissions. Advanced incineration plants are constructed throughout with dioxin removal facilities such as selective catalytic reduction [9]. Again, presence of Sulphur as well as combination of extreme temperatures, high heating value fuel, available oxygen and greater residence times prevent the formation of PCDD/Fs viz temperatures greater than $700{ }^{\circ} \mathrm{C}$ can result in $99 \%$ destruction for PCBs without any of the toxic by-products formation ${ }^{[10]}$.

\section{Photodegradation/Photolysis}

Another possible remediation technology is the photolysis of PCBs. Advancement in research depicted use of catalysts to enhance rate of photolysis. Among them, $\mathrm{TiO}_{2}$ based catalysts have shown greater photocatalytic degradation such as nafion coated $\mathrm{TiO} 2$ particles $(\mathrm{Nf} / \mathrm{TiO} 2)$, carbon-modified titanium dioxide (CM-n-TiO2) nanoparticles and platinum loaded $\mathrm{TiO} 2(\mathrm{P} 25)$ catalysts etc ${ }^{[11]}$. Again, graphitic carbon nitride (g-C3N4), a non-metal $\pi$ conjugated polymeric semiconductor, was reported for the photocatalytic degradation of PCBs because it has some unique properties of chemical and thermal stability, low-cost, non toxicity, re-usability, optoelectric property, molecular tunability, and visible light responsive nature. Besides, $\mathrm{TiO} 2 / \mathrm{gC} 3 \mathrm{~N} 4$, graphene/g-C3N4, $\mathrm{ZnO} / \mathrm{g}-\mathrm{C} 3 \mathrm{~N} 4, \quad \mathrm{MoS} 2 / \mathrm{g}-\mathrm{C} 3 \mathrm{~N} 4, \quad \mathrm{Bi} 2 \mathrm{WO} / \mathrm{g}-\mathrm{C} 3 \mathrm{~N} 4$ are considered as supported photocatalysts that have already displayed stupendous degradation property than metal-free gC3N4 photocatalysts ${ }^{[12]}$.

\section{Advanced Oxidation Process}

One example of advanced oxidation process is the rapid destruction of PCBs by Fenton's reaction in aqueous solutions. In Fenton's reaction, combination of $\mathrm{H}_{2} \mathrm{O}_{2}$ with $\mathrm{Fe}^{2+}$ generates hydroxyl radicals ( $\mathrm{HO} \cdot$ ) may be in presence or absence of light. However, in most cases, $\cdot \mathrm{OH}$ are effective only under acidic conditions. But sulfate radicals $\left(\mathrm{SO}^{\circ-}\right)$ are more powerful oxidants as compared to $\bullet \mathrm{OH}$ radicals due to its high redox potential $(2.5-3.1 \mathrm{~V})$ and a wide $\mathrm{pH}$ range of 2.0-8.0 [13]. Besides, high water solubility, subsurface stability, cost effectiveness and benign end products proved $\mathrm{SO}^{--}$as a brilliant choice among AOPs for mitigating PCBs from contaminated soil, sediment and groundwater. However, chloride ion, being the major product of reaction of chlorinated organic contaminants on oxidation with $\mathrm{SO}^{\cdot-}$, decreases the reactivity of sulfate radical system ${ }^{[14]}$. More recently, different AOPs were reported for PCBs decomposition in which sulfate radicals were generated by a variety of metals including $\mathrm{Fe}(\mathrm{II}), \mathrm{Fe}(\mathrm{III}), \mathrm{V}(\mathrm{III}), \mathrm{V}(\mathrm{IV})$ and $\mathrm{V}(\mathrm{V})$ and some nanomaterials. Most of sulfate radical systems showed effective performance towards removal of PCBs ${ }^{[15]}$.

\section{Capping and Natural Attenuation}

Capping is also an age old practice including the covering of the contaminated soil. It is a means of not destroying the material but here it isolates the contaminant from the environment. In order to make it more reusable some sort of soil amendments are mixed with it leading to the land farming technology. Again sorption into organic matter, biodegradation, dilution of the chemical, chemical reactions to destroy them and evaporation leads to monitored natural attenuation which is seldom used in PCB waste remediation.

\section{De-chlorination by Chemical Reagent}

PCBs can be destroyed using chemical reagents with high temperatures and pressures. Different chemical reagents have been used and amidst them most common are $\mathrm{Zn}$ and $\mathrm{Mg} /$ acidic or basic solution, Fenton's reagent, and lower valent metals (alkali metal in alcohol) ${ }^{[16]}$. About 90 years back, dehlaogenation was first implemented using chemical reagents e.g commercially phenol was used to dehalogenate furans and dlPCBs. Dehalogenation of congeners proved to be more efficient than biological treatments because of its rapidity ${ }^{[17]}$. 
A study on PCB elimination was held using $\mathrm{Ca}$ in ethanol under room temperature and normal atmospheric pressure for $24 \mathrm{hr}$ and interestingly it depicted about $98 \%$ reduction in levels of toxic PCBs ${ }^{18}$. Ryoo et al., (2007) ${ }^{[19]}$ developed an elimination technique in which $\mathrm{KOH}$, aluminium and polyethylene glycol 600 have been used for PCB disposal. Results of the technique showed that on an average, PCB remediation efficiency stood about $78 \%$ at $100{ }^{\circ} \mathrm{C}$ with $2 \mathrm{~h}$, which enhanced to $99 \%$ at $150{ }^{\circ} \mathrm{C}$ and $4 \mathrm{~h}$, particularly for PCB-77, PCB-118, PCB-123, PCB-169, and PCB105. Recently, Nah et al. (2008) [20] implemented fine metal powder, glycol and alkali to mitigate PCBs from waste insulating oil resulting in a removal efficiency of $99.9 \%$ for total PCB concentration. Further, some studies reported that a combination of chemical solutions and catalysts i.e., catalytic hydro dehalogenation, can result in a higher dechlorination performance ${ }^{[21]}$. Extensive research has been conducted on catalytic hydro dehalogenation of PCBs. Such a combination of chemical solution and catalysts could allow PCB dehalogenation in short times under mild conditions (e.g., ambient temperature) with low energy requirement ${ }^{[22]}$.

Table 1: Bimetallic Systems Used for Hydro dehalogenation of Chlorinated Biphenyls [29]

\begin{tabular}{|c|c|c|c|c|}
\hline $\begin{array}{c}\text { Bimetallic } \\
\text { systems }\end{array}$ & Compounds & Operating Conditions & Findings & References \\
\hline $\mathrm{Al} / \mathrm{Pd}$ & 2- chlorobiphe-nyl & $\begin{array}{c}50 \mathrm{~mL} \text { solution of } 2-\mathrm{PCB} \text { was added into a } 100 \\
\mathrm{~mL} \text { serum bottle with } 5.0 \mathrm{~g} / \mathrm{L} \text { of } \mathrm{Al} / \mathrm{Pd} \text { loading and } \\
\text { fixed on a horizontal shaker }(180 \mathrm{rpm}) \text { at ambient } \\
\text { temperature }\end{array}$ & \begin{tabular}{|c|} 
2-PCB was completely \\
dechlorinated into BP within \\
60 min by the 1.43 wt. $\%$ of \\
$\mathrm{Al} / \mathrm{Pd}$
\end{tabular} & 23 \\
\hline $\mathrm{Fe} / \mathrm{Pd}$ & $\begin{array}{l}\text { Tetrachlorobiphenyl (TeCB), } \\
\text { PCB77, Aroclor } 1254\end{array}$ & $\begin{array}{c}\text { PCBs combined } 5 \mathrm{~g} \text { of } \mathrm{Pd} / \mathrm{Fe} \text { were placed in a vial } \\
\text { with } 500 \mathrm{ml} \text { of ethanol and isopropanol solution } \\
\text { and shaken for } 16 \mathrm{~h} \text {. } \\
\text { The degradation was initiated by injecting } 25 \mu \mathrm{L} \\
\text { of Aroclor } 1254(100 \mathrm{mg} \mathrm{L}-1) \text { into } 1 \mathrm{~mL} \text { of } \\
\text { solution per vial containing } 1 \mathrm{~g} / \mathrm{L} \text { as Fe of a } \\
\text { certain type of nanoparticles. } \\
\text { Polypyrrole film }\left(16.2 \mathrm{~cm}^{2}\right) \text { containing Pd } \\
\text { nanoparticles was added to } 20 \text { - } \mathrm{mL} \text { solution of } \\
\text { PCB } 77\end{array}$ & $\begin{array}{c}\text { TeCB was completely } \\
\text { transformed to biphenyl in } 9 \mathrm{~h} \text {. } \\
\text { Aroclor } 1254 \text { was resulted in a } \\
24 \% \text { reduction within } 100 \mathrm{~h} \text {, } \\
85 \% \text { of PCB } 77 \text { degraded } \\
\text { within } 2 \mathrm{hrs}\end{array}$ & $24-26$ \\
\hline $\mathrm{Mg} / \mathrm{Pd}$ & $\begin{array}{c}\text { 2-Monochlorobiphenyl 3- } \\
\text { Monochlorobiphenyl 4- } \\
\text { Monochlorobipheny and Mix of } \\
\text { congeners }\end{array}$ & $\begin{array}{c}0.25 \mathrm{~g} \text { of } \mathrm{Mg} / \mathrm{Pd} \text { and } 10 \mathrm{~mL} \text { of PCB solution were } \\
\text { added into } 20 \mathrm{~mL} \text { vials and were shaken for } 2 \mathrm{~min} \text {. } \\
\text { Analysis was done in GC/DSQ. } \\
\text { The contaminated substrate was mixed with } \\
\mathrm{Mg} / \mathrm{Pd} \text { and contacted intimately by tumbling at } 20 \\
\mathrm{rpm} . \mathrm{PCB} \text { extracts }(0.5 \mathrm{~mL}) \text { were spiked with } 10 \\
\mu \mathrm{L} \text { of } 200 \text { ppm D-8 naphthalene in DCM and } \\
\text { analysed in a GC/MS }\end{array}$ & $\begin{array}{c}\text { The rate of dechlorination for } \\
\text { monochlorinated congeners in } \\
\text { water was PCB-003 > PCB- } \\
002>\text { PCB-001. } \\
\text { The PCBs changed from a } \\
\text { higher chlorinated to lower } \\
\text { congeners at the end of } 26 \mathrm{~h} .\end{array}$ & $27-28$ \\
\hline
\end{tabular}

\section{Activated Carbon based removal of PCBs}

A widely used method for mitigating hazardous inorganic and organic chemicals is adsorption using Activated carbon. They have highly porous structure and this helps in increasing surface area (500-2,500 $\mathrm{m}^{2} / \mathrm{g}$ ) for adsorption and further chemical reactions. Amidst the naturally occurring, cost effective and renewable method, coconut shell, hardwood, rice husk, bamboo, lignite, bark husk, maize cob, peanut hull, sawdust, coir pith, and pall fiber etc have been conventionally used as activated carbons ${ }^{[30]}$. Furthermore, depending on the size of pores, activated carbon can be differentiated into three categories including macropores, mesopores and micropores (diameter $<50 \mathrm{~nm})^{[31]}$. Morphology of activated carbon also plays a significant role in adsorption of organic pollutants. Based on the morphological features, they can be classified as powdered activated carbon (PAC), granular activated carbon (GAC), activated carbon fibers (ACFs), bead activated carbon (BAC), and carbon nanotubes (CNTs) etc. At the Hunters Point Sipyard near San Franscisco, a pilot study depicted that for a period of 60 months, approximately $73 \%$ of the PCBs have been transferred from sediments to the aqueous bodies just due to addition of activated carbon (3.7\% dry wt.) into the sediment ${ }^{[32]}$. The removal efficiency of GAC and PAC was evaluated by Vasilyeva et al. (2010) ${ }^{[33]}$ in a soil previously contaminated with PCBs. Kjellerup and Edwards (2013) [34] applied sequestration methodology using granular activated carbon for elimination PCBs from contaminated sediments. Recently, biochar provided $89 \%$ reduction in PCBs bioavailability in historically contaminated sediments ${ }^{[35]}$.
Furthermore, a bunch of auxiliary techniques have been implemented along with activated carbon including microwave decomposition and/or catalysts ${ }^{[36]}$. Some of the multi-technology approaches are; PCB 29(2,4,5trichlorobiphenyl) remediation form contaminated soils using microwave and granular activated carbon ${ }^{[37]}$, Simultaneous adsorption and dehalogenation of congeners through synthesis of reactive nano-Fe/pd bimetallic system impregnated activated carbon ${ }^{[38]}$, substituted chlorines of high-chlorinated PCB congeners by activated carbon impregnated with $\mathrm{Fe}$ coupled with Pd. It is of note that considerable studies have been done on PCB remediation inoculating combination of activated carbon and anaerobic bacterial biofilm wherein activated carbon served as a microbial inoculum delivery system. This opened the door towards the purposeful usage of combination technologies for outstanding success ${ }^{[39]}$

\section{Modern Technology for PCB waste Remediation Supercritical Water Oxidation}

It is a technology which occurs in water at temperatures and pressures above the critical point $(647 \mathrm{~K} \text { and } 22.064 \mathrm{MPa})^{[40]}$. This supercritical condition transform water from a polar to non polar solvent due to loss of hydrogen bonds. Therefore, solubility of PCBs in supercritical water start increasing. Example of some efficient commercially used SCWO system includes an operating condition of $550-650{ }^{\circ} \mathrm{C}, 250$ bar pressure and most importantly it proved to be highly efficient, achieving over $99 \%$ PCB destruction ${ }^{[41]}$. Weber et al. (2002) [42] also documented over $99 \%$ PCBs destruction under 
supercritical water with an alkaline environment. In presence of excess oxygen also, SCWO is capable of $93 \%$ decomposition of decachlorobiphenyl ${ }^{[43]}$. Marulanda and Bolaños (2010) ${ }^{[40]}$ showed in a study that about $99.6 \%$ of the mixture of PCBs and hydrocarbons was destroyed from PCBcontaminated oil of a large scale mineral PCB transformer with $350 \%$ excess oxygen at about $539{ }^{\circ} \mathrm{C}$. Researchers have analysed SCWO extensively and concluded that salt accumulation over the surface of equipment is a major problem which further requires high maintenance cost and other operational maintenance procedures.

\section{Ultrasonic Radiation}

Ultrasonic radiation is one of most promising technology for PCB remediation in which acoustic cavitation takes the major role ${ }^{[44]}$. Acoustic cavitation is a mechanical activation process that destroys the attractive forces of molecules in the liquid phase and thus it allows bubble growth through vapor diffusion of solutes ${ }^{[45]}$. The energy present inside the bubbles will therefore release and lead to an increase in the temperatures and pressures in the microscopic regions. This finally results in chemical excitation and chemical bond breaks. So, PCB degradation can be carried out effectively using this method and simple handling conditions like low temperatures and fast reaction times added an extra flavour to it. Ultrasonic radiation shows very high $\mathrm{PCB}$ removal efficiencies of greater than $90 \%$ from environmental matrices [46]. Furthermore, Rodríguez and Lafuente (2008) [47] evaluated the dechlorination of PCB mixtures with ultrasonic radiation system having temperature of $40{ }^{0} \mathrm{C}$ with a hydrazine hydrochloride/palladium (HZ/Pd) catalyst. About $80-90 \%$ degradation of 2-chlorobiphenyl, 4-chlorobiphenyl and 2,2' -dichlorobiphenyl in aqueous solutions was observed by Okuno et al,(2000) ${ }^{[48]}$ in about 30-60 min with $200 \mathrm{kHz}$ ultrasound. A laboratory scale application of UR on 4chlorobiphenyl contaminated sediments depicted that more than $90 \%$ of the analyte in the aqueous, homogeneous solution was decomposed at $20 \mathrm{kHz}$ ultrasound with power density of $460 \mathrm{~W} / \mathrm{L}$ after 20 mins ${ }^{[49]}$. Recently introduction of ultrasound assisted chemical process (UACP) promotes a new horizon in PCB remediation technique. In a study, Chen et al. (2013) ${ }^{[50]}$ dechlorinated Aroclor 1260 by using a combination of ultrasonic irradiation and radical generations via di-tertbutyl peroxide as radical initiator. Results showed that UACP is more effective for PCBs remediation with $97 \%$ removal within $3 \mathrm{~h}$. But it is a costly and not easy to be operated, moreover requirement of higher energy is also a constraint behind adoption of this technique for PCB removal.

\section{PCBs removal by Electrokinetic Remediation}

Electrokinetic remediation, an in-situ method, removes persistent organic pollutants from various environmental matrices including soil by using low-level direct current as a "cleaning agent" [51]. This often consists an external, direct current source, along with an anode and cathode immersed in the electrolytic solution. When the direct current is applied, the organic pollutants driven by ionic migration or electrophoresis will move towards the favourable electrodes. Other technologies like nZVI dehalogenation when coupled with electrokinetic remediation established a new stage in PCB remediation ${ }^{[52]}$. PCBs have been eliminated also from contaminated soil using electrokinetic energy coupled with nano $\mathrm{Pd} / \mathrm{Fe}$ bimetallic nanoparticles ${ }^{[53]}$. They found that though the degradation was little bit slow as PCBs were strongly bound to the soil particles, high electroosmotic flow facilitates nano $\mathrm{Pd} / \mathrm{Fe}$ transport. Gomes et al. (2014) ${ }^{[54]}$ proposed the use of electrodialytic remediation combined with nZVI particles as a cost-effective way to remediate PCB contaminated soil. Electrodialytic remediation consists of the electrokinetic movement of ions for elimination of heavy metals ${ }^{[55]}$. They also used two surfactants namely saponin and Tween 80 in this study to increase PCB desorption and removal from contaminated soil. The outcome of the experiment exhibit that the removal efficiencies of highly chlorinated PCB congeners (penta-, hexa-, hepta-, and octachlorobiphenyl) ranges between 9 and 96\%. Chun et al. (2013) ${ }^{[56]}$ introduced an inventive approach for the effective dehalogenation of PCBs in contaminated sediment using electrical stimulation, which supplies electron acceptors and donors to PCB dechlorinating microorganisms. They experimented out that the concentration of weathered PCBs declined 40-60\% from its original concentrations which was about $20 \mathrm{mg} / \mathrm{kg}$ dry sediments, in microcosms subjected to electric current than that of PCBs observed in control reactors.

\section{nZVI with another Metal combination}

Nano zero valent iron in combination with other metals can be a potential alternative for remediating $\mathrm{PCBs}$ as it can also be capable of overcoming the deficiencies due to individual treatments ${ }^{[57]}$. For the past few years, nZVI has been proved efficient in treating wide spectrum of contaminants like chlorinated \& brominated methanes, trihalomethanes, chlorinated ethenes and benzenes, and some other polychlorinated hydrocarbons ${ }^{[58]}$. nZVI particles when covered with metals, becomes efficient in reducing the activation energy barriers as well as increasing the dechlorination reaction rates ${ }^{[59]}$. Additionally, increase in surface area and surface reactivity of metal coated NZVI added an extra flavour in rapid dechlorination process ${ }^{[60]}$. Zhuang et al. (2011) [61] evaluated palladized nZVI for mitigation of 2,3,4-trichlorobiphenyl (PCB-21) and the results suggested that the degradation rate of $\mathrm{PCB}-21$ (normalized rate constant of $10-1$ ) by using $\mathrm{Pd} / \mathrm{nFe}$ was 3 orders of magnitude faster than that of PCB-21 when using unpalladized ZVI (normalized rate constant of 10-4 ). Le et al., (2015) ${ }^{[62]}$ developed an integrated remediation system for dehalogenation of Aroclor 1248 using bimetallic nanoparticles $\mathrm{Pd} / \mathrm{nFe}$ and biodegradation via burkholderia xenovorann LB400 whereas Horvathova et al., 2019 [63] developed an effective comparison study of bionanoremediation and nano-bioremediation using nZVI and bacteria $O$. anthropi from the sediment. In the first study, The dehalogenation efficiencies of tri-, tetra-, penta-, and hexachlorinated biphenyls were 99, 92, 84, and 28\%, respectively while in second case about $77 \%$ degradation was found for hexa congeners by nano bioremediation strategy.

\section{Biofilm Covered Activated Carbon}

During early 1970s biofilm covered activated carbon particles was found efficient in removing organic pollutants64. Since then, the combined application of activated carbon and bacterial biofilm gained popularity as a practiced remediation technique for wastewater treatment, water purification, and elimination of organic contaminants ${ }^{[65]}$. Recently a report suggested that biofilm treatment along with activated carbon adsorption can significantly treat naphthenic acids in oil sand process affected waters (OSPW). The results of these successful experiments have emphasized the acceptance of the combined application as a viable tool for mitigating PCBcontaminated sediment as suggested by the USEPA. 
Moreover, a bench scale study on PCB bioaugmentation in liquid wastes showed that with the use of GAC, one can be able to remove about $62 \%$ of PCBs [66]. Additionally, bioaccumulation of PCBs in clams, worms, and amphipods can be reduced by treating the sediment with $1-5 \%$ (w/w) of GAC as indicated by a field study. During 1- and 6-month experimental time period, sediments treated with $3.4 \%$ of coke activated carbon exhibited 85 and $92 \%$ reductions in aqueous equilibrium PCB concentrations respectively ${ }^{[67]}$. But due to scarcity of microorganisms, a combined application of adsorbent sequestration and bioaugmentation through biofilm covered activated carbon systems is suggested to increase the biodegradation of low concentration PCBs in sediment. Kjellerup and Edwards (2013) ${ }^{[34]}$ suggested that the biofilm covered activated carbon system generally has a removal efficiency of over $60 \%$ because of simultaneous adsorption and biodegradation. A compact space between biofilms with large cell density and activated carbon surface enables the degradation by allowing microorganisms to exploit PCBs as an electron acceptor. Additionally, the microorganism nested within adherent biofilm achieve a high toxic pollutants resistivity ${ }^{[68]}$. Moreover, a biofilm coated activated carbon systems has the ability to maintain long solid retention times which results in biodegradation of persistent organics at a low growth rate ${ }^{[69]}$.

\section{Magnetic Composites for PCB removal}

Magnetic nanomaterials were extensively investigated for adsorption of PCBs from water and wastewater treatment plants, with an effective separation via application of an external magnetic field ${ }^{[70]}$. nZVI particles having diameter of $<100 \mathrm{~nm}$ and a core-shell structure are highly reactive with water and oxygen to form an outer hydroxide layer in aqueous conditions. This outer oxide layer further promotes transfer of electrons from the metal through the oxide conduction band or localized band thus could serve as an adsorbent for PCBs. Dehalogenation of alkyl halides (RX) was reported in 1994 by Schreier and Reinhard ${ }^{[71]}$, who depicted that Fe powder in oxygen free and buffered water can be efficient for the process but it was difficult to predict outcomes. Since then, a novel 3 step mechanism was adopted for dehalogenation purposes ${ }^{[72]}$. In acidic environment electrons can directly transfer from $\mathrm{Fe}^{0}$ to the $\mathrm{PCB}$ molecules and produces $\mathrm{Fe}^{2+}$. Further in a study, iron oxides and $\mathrm{V}_{2} \mathrm{O}_{5} / \mathrm{TiO}_{2}$ have been used together for effective removal of more than $95 \%$ of 10 different PCB congeners which have concentrations at a range of up to $1 \mathrm{mg} / \mathrm{kg}$ filter cake or soil [73]. Long et al. (2014) ${ }^{[74]}$ experimented out that dehalogenation of Aroclor 1260 in soil can be increased by practising anaerobic composting with nZVI. To eliminate out TrCB and TeCB from water effectively, Liu et al. (2014) ${ }^{[75]}$ used thermal desorption technique along with $\mathrm{nZVI}$ at different temperature conditions $\left(300^{\circ}-600{ }^{\circ} \mathrm{C}\right)$. But scientists also reported some cases related to toxic impact of nZVI. Some composite materials like a synthesized magnetic nanomaterial having oxide graphene as a functional group along with $\mathrm{Fe}_{3} \mathrm{O}_{4}$ also proved to be efficient to remove PCB contamination ${ }^{[76-77]}$. Zeng et al. (2013) ${ }^{[78]}$ further experimented out the efficacy of $\mathrm{Fe}_{3} \mathrm{O}_{4}$ grafted graphene oxide for removal of PCB 28 from a volume of contaminated water through magnetic solid-phase extraction technique. Results of further experiments suggested that $91 \%$ of the PCB 28 can be extracted from the nanoparticles by hexane/dichloromethane. Likewise, dispersion of a mixture of $\mathrm{Fe}_{3} \mathrm{O}_{4}$ and ammonium chloride on graphene oxide sheets $\left(\mathrm{Fe}_{3} \mathrm{O}_{4} @ \mathrm{PDDA} / \mathrm{GO}_{\mathrm{x}} @ \mathrm{DNA}\right)$ also showed high removal efficiencies $(99.1 \%)$ for PCB from $100 \mathrm{~mL}$ water in $30 \mathrm{~min}{ }^{[79]}$. Li et al. (2016) ${ }^{[80]}$ developed a compiled adsorbent, metal organic nanotube $\left(\mathrm{Fe}_{3} \mathrm{O}_{4} @ \mathrm{Co}-\right.$ MONT) for the removal of PCB from wastewater. Choi et al. (2008) [38] observed the efficacy of $\mathrm{Fe} / \mathrm{Pd}$ bimetallic nanomaterial system for PCB adsorption and they found that it adsorbed almost $100 \%$ PCB present in water within 2 days of application at room temperature and $\mathrm{pH}$ 6.5. Further studies exhibits that $\mathrm{Fe}_{3} \mathrm{O}_{4}$ along with betacyclodextrin resulted a polymer that increase the removal of PCBs from water with $100 \%$ removal in $30 \mathrm{~min}^{[81]}$. Zhao et al. (2013) ${ }^{[82]}$ found that bamboo charcoal-modified $\mathrm{Fe}_{3} \mathrm{O}_{4}$ nanosheets can be successfully used for the removal of PCB from wastewater by achieving a $98.4 \%$ removal rate. Some photocatalytic nanocomposites are also found to be potent in removal of PCBs from various matrices. $\mathrm{TiO}_{2}$ nanoparticles showed promising result for purification of waste water through photocatalysis ${ }^{[83]}$. Besides, its ability to remove Pthalic acid esters, Shaban et al. (2016) ${ }^{[84]}$, found that the photocatalytic efficiency of carbonmodified titanium oxide nanoparticles (CM-n-TiO2) is very high (93\%) when subjected to PCB contaminated water. The results of the photodegradation experiment confirmed that the value of $0.5 \mathrm{~g} / \mathrm{L}$ of nanomaterial dose is ample for the remediation of high concentration of PCB under favourable condition for $24 \mathrm{~h}$ in acidic (pH 5) media. Other nanocomposites such as velvetlike magnetic carbon nitride nanocomposites $\left(\mathrm{V}-\mathrm{g}-\mathrm{C}_{3} \mathrm{~N}_{4}\right)$, synthesized by chemical co-precipitation, may also work effectively. The above mentioned materials were used to formulate a solid-phase extraction method to extract out PCB from water samples and the results showed that $100 \%$ removal of PCB was achieved for $3 \mu \mathrm{g} / \mathrm{L}$ of PCB within $3 \mathrm{~s}$ ${ }^{[85-86]}$. Wu et al. (2015) ${ }^{[87]}$ reported that graphene oxide sheets scattered with gold nanoparticles (RGO-AuNp) exhibits high selectivity toward adsorption of PCB 77. Moreover, several studies on nanoclays revealed high affinity of these materials toward PCB remediation. Sevcu et al. (2017) ${ }^{[88]}$ sought out an optimized removal method for PCB $(97.5 \%)$ from water after $24 \mathrm{~h}$ contact time. They basically carried out the PCB removal process at $\mathrm{pH}$ values higher than 7.5 in room temperature with a concentration of $1 \mathrm{~g} / \mathrm{L}$ of nanoscale zerovalent iron in the contaminated water.

Table 2: Nanomaterials used for Effective Removal of PCBs with Mechanism of Removal [97]

\begin{tabular}{|c|c|c|c|c|}
\hline Nanomaterial & \% removal & Mechanism & Isotherm & References \\
\hline $\begin{array}{c}\text { Methyl methacrylate on multiwalled-carbon nanotube(MWCNT- } \\
\text { gpMMA) }\end{array}$ & $95 \%$ & Adsorption & $\begin{array}{c}\text { Langmuir model, Pseudo-frst } \\
\text { order }\end{array}$ & 89 \\
\hline $\begin{array}{c}\text { Multiwalled-carbon nanotubes grafted cyclodextrin (MWCNT-g-CD } \\
\text { Graphene Oxide }\end{array}$ & $995 \%$ & Adsorption & Langmuir model & 90 \\
\hline $\begin{array}{c}\text { Amino- functionalized polypropylene nonwoven graphene oxide } \\
\text { (PP-g-DMAEMA/GO }\end{array}$ & $85 \%$ & Adsorption & Langmuir, Freundlich and PDM & $91-92$ \\
\hline Adsorption & Pseudo-1 $1^{\text {st }}$ Order & 93 \\
\hline metal organic nanotube (Fe3O4@ Co-MONT) & $100 \%$ & Adsorption & - & 94 \\
\hline
\end{tabular}




\begin{tabular}{|c|c|c|c|c|}
\hline Bamboo charcoal iron oxide (BC@Fe) & $98.4 \%$ & SPME & - & 82 \\
\hline $\begin{array}{c}\mathrm{Fe} 3 \mathrm{O} 4 \text { with ammonium chloride dispersed on graphene oxide sheets } \\
\text { (Fe3O4@ PDDA/ GOx@ DNA) }\end{array}$ & $99.1 \%$ & SPME & Langmuir & 79 \\
\hline Metal grafted graphene oxide (Fe3O4@GO) & $100 \%$ & MSPE & Pseudo $2^{\text {nd }}$ Order & 78 \\
\hline $\mathrm{Fe} 3 \mathrm{O} 4$ beta-cyclodextrin & $100 \%$ & Adsorption & Langmuir & 81 \\
\hline Nano-Fe/Pd bimetallic & $100 \%$ & Adsorption & Pseudo- $1^{\text {st }}$ order & 38 \\
\hline Carbon-modifed titanium oxide nanoparticles (CMn-TiO2) & $93 \%$ & $\begin{array}{c}\text { Photocatalytic } \\
\text { degradation }\end{array}$ & Langmuir & 84 \\
\hline Nanoscale zero-valent iron (NZVI) & $100 \%$ & Adsorption & - & 95 \\
\hline Velvet-like magnetic carbon nitride nanocomposites (V-g-C3N4) & $100 \%$ & Adsorption & Langmuir and Freundlich & 85 \\
\hline Nanoclays & $77 \%$ & Adsorption & Langmuir and Freundlich & 96 \\
\hline
\end{tabular}

\section{Conclusion and future prospects}

The current review depicted the remediation strategies of PCBs. Use of chemical reagents, supercritical water oxidation, ultrasonic radiation, bimetallic systems, nZVI, and nZVI combination with a second metal have a high remediation efficiency (78-99\%) with a rapid reaction time. Due to this fact, physicochemical approaches tend to be more effective than ecological remediation approaches. Activated carbon and the biofilm covered activated carbon approaches obtained the highest scores as compared to the technologies mentioned above. A low cost and relatively high remediation efficiency (more than 60\%) allow them to be applied to either in-situ or ex-situ PCBs remediation. PCBs are complex chemicals, so knowledge of their chemical and physical properties is important to better understand their transport and fate thereby for selecting appropriate remediation approaches. The possibility of PCB remediation by using multiple technologies discussed in this paper need more data and pilot scale experiments in order to evaluate the effectiveness. The future vision of PCB remediation could be a comprehensive treatment solution. Because successful treatment of PCBs not only depends on the appreciated selection of the most effective remediation technology, it is also necessary to consider the public acceptance and environmental and human health impacts of the remediation technology, neither of which have been achieved.

\section{References}

1. Lallas PL. The Stockholm Convention on persistent organic pollutants. The American Journal of International Law. 2001; 95(3):692-708.

2. Van den Berg M, Birnbaum LS, Denison M, De Vito M, Farland W, Feeley M et al. The 2005 World Health Organization reevaluation of human and mammalian toxic equivalency factors for dioxins and dioxin-like compounds. Toxicological sciences. 2006; 93(2):223-41.

3. Schecter A, Birnbaum L, Ryan JJ, Constable JD. Dioxins: an overview Environ Res Find this article online. 2006; 101(3):419-428.

4. Agarwal S, Al-Abed SR, Dionysiou DD. In situ technologies for reclamation of PCB-contaminated sediments: current challenges and research thrust areas.

5. Lavandier R, Quinete N, Hauser-Davis RA, Dias PS, Taniguchi S, Montone R et al. Polychlorinated biphenyls (PCBs) and polybrominated diphenyl ethers (PBDEs) in three fish species from an estuary in the southeastern coast of Brazil. Chemosphere. 2013; 90(9):2435-43.

6. Huang J, Matsumura T, Yu G, Deng S, Yamauchi M, Yamazaki N et al. Determination of PCBs, PCDDs and PCDFs in insulating oil samples from stored Chinese electrical capacitors by HRGC/HRMS. Chemosphere. 2011; 85(2):239-46.

7. Eckhardt S, Breivik K, Man S, Stohl A. Record high peaks in $\mathrm{PCB}$ concentrations in the Arctic atmosphere due to long-range transport of biomass burning emissions.

8. Weidemann E, Lundin L. Behavior of PCDF, PCDD, PCN and PCB during low temperature thermal treatment of MSW incineration fly ash. Chemical Engineering Journal. 2015; 279:180-7.

9. Han JH, You F, Li P, Dong Q, Qin SH, Fan DD. Properties and Reliability Evaluation of Consecutive Pyrolysis and Incineration Disposal Process for FR-4 Waste Printed Circuit Boards. Procedia engineering. 2018; 211:205-14.

10. Yaghmaeian $\mathrm{K}$, Jaafarzadeh $\mathrm{N}$, Nabizadeh $\mathrm{R}$, Dastforoushan G, Jaafari J. CFD modeling of incinerator to increase PCBs removal from outlet gas. Journal of Environmental Health Science and Engineering. 2015; 13(1):60.

11. Ghosh JP, Achari G, Langford CH. Reductive dechlorination of PCBs using photocatalyzed UV light. CLEAN-Soil, Air, Water. 2012; 40(5):455-60.

12. Prakash K, Kumar PS, Latha P, Saravanakumar K, Karuthapandian S. Design and fabrication of a novel metal-free $\mathrm{SiO} 2 / \mathrm{gC} 3 \mathrm{~N} 4$ nanocomposite: a robust photocatalyst for the degradation of organic contaminants. Journal of Inorganic and Organometallic Polymers and Materials. 2018; 28(1):268-78.

13. Fang GD, Dionysiou DD, Wang Y, Al-Abed SR, Zhou DM. Sulfate radical-based degradation of polychlorinated biphenyls: effects of chloride ion and reaction kinetics. Journal of hazardous materials. 2012; 227:394-401.

14. Fang $\mathrm{G}$, Wu W, Deng $\mathrm{Y}$, Zhou D. Homogenous activation of persulfate by different species of vanadium ions for PCBs degradation. Chemical Engineering Journal. 2017; 323:84-95.

15. Wang J, Wang S. Activation of persulfate (PS) and peroxymonosulfate (PMS) and application for the degradation of emerging contaminants. Chemical Engineering Journal. 2018; 334:1502-17.

16. Kulkarni PS, Crespo JG, Afonso CA. Dioxins sources and current remediation technologies-a review. Environment international. 2008; 34(1):139-53.

17. Huling SG, Pivetz BE. In situ Chemical Oxidation (EPA/600/R-06/072). US EPA, 2006.

18. Mitoma Y, Uda T, Egashira N, Simion C, Tashiro H, Tashiro $\mathrm{M}$ et al. Approach to highly efficient dechlorination of PCDDs, PCDFs, and coplanar PCBs using metallic calcium in ethanol under atmospheric pressure at room temperature. Environmental science \& technology. 2004; 38(4):1216-20.

19. Ryoo KS, Byun SH, Choi J, Hong YP, Ryu YT, Song JS et al. Destruction and removal of PCBs in waste transformer oil by a chemical dechlorination process. Bulletin-Korean Chemical Society. 2007; 28(4):520.

20. Nah IW, Hwang KY, Shul YG. Effect of metal and glycol on mechanochemical dechlorination of 
polychlorinated biphenyls (PCBs). Chemosphere. 2008; 73(1):138-41.

21. $\mathrm{Xu} \mathrm{J}$, Bhattacharyya D. Fe/Pd nanoparticle immobilization in microfiltration membrane pores: Synthesis, characterization, and application in the dechlorination of polychlorinated biphenyls. Industrial \& engineering chemistry research. 2007; 46(8):2348-59.

22. Ehsan S, Prasher SO, Marshall WD. Estimates of total polychlorinated biphenyl (PCB) compounds in soils/sediments by hydrogenolysis to dicyclohexyl. Journal of Environmental Monitoring. 2003; 5(4):644-8.

23. Yang B, Deng S, Yu G, Zhang H, Wu J, Zhuo Q. Bimetallic Pd/Al particles for highly efficient hydrodechlorination of 2-chlorobiphenyl in acidic aqueous solution. Journal of hazardous materials. 2011; 189(1-2):76-83.

24. Korte NE, West OR, Liang L, Gu B, Zutman JL, Fernando Q. The effect of solvent concentration on the use of palladized-iron for the step-wise dechlorination of polychlorinated biphenyls in soil extracts. Waste Management. 2002; 22(3):343-9.

25. He F, Zhao D. Preparation and characterization of a new class of starch-stabilized bimetallic nanoparticles for degradation of chlorinated hydrocarbons in water. Environmental science \& technology. 2005; 39(9):331420.

26. Venkatachalam K, Arzuaga X, Chopra N, Gavalas VG, $\mathrm{Xu}$ J, Bhattacharyya D, Hennig B et al. Reductive dechlorination of 3, 3', 4, 4'-tetrachlorobiphenyl (PCB77) using palladium or palladium/iron nanoparticles and assessment of the reduction in toxic potency in vascular endothelial cells. Journal of hazardous materials. 2008; 159(2-3):483-91.

27. DeVor R, Carvalho-Knighton K, Aitken B, Maloney P, Holland E, Talalaj et al. Dechlorination comparison of mono-substituted $\mathrm{PCBs}$ with $\mathrm{Mg} / \mathrm{Pd}$ in different solvent systems. Chemosphere. 2008; 73(6):896-900.

28. Agarwal S, Al-Abed SR, Dionysiou DD. A feasibility study on $\mathrm{Pd} / \mathrm{Mg}$ application in historically contaminated sediments and PCB spiked substrates. Journal of hazardous materials. 2009; 172(2-3):1156-62.

29. Jing R, Fusi S, Kjellerup BV. Remediation of polychlorinated biphenyls (PCBs) in contaminated soils and sediment: state of knowledge and perspectives. Frontiers in Environmental Science. 2018; 6:79.

30. Das D, Samal DP, Meikap BC. Preparation of activated carbon from green coconut shell and its characterization. Journal of Chemical Engineering \& Process Technology. 2015; 6(5):1-7.

31. Kim M, Oh I, Kim J. Supercapacitive behavior depending on the mesopore size of three-dimensional micro-, mesoand macroporous silicon carbide for supercapacitors. Physical Chemistry Chemical Physics. 2015; 17(6):442433.

32. Choi H, Al-Abed SR, Agarwal S. Catalytic role of palladium and relative reactivity of substituted chlorines during adsorption and treatment of PCBs on reactive activated carbon. Environmental science \& technology. 2009; 43(19):7510-5.

33. Vasilyeva GK, Strijakova ER, Nikolaeva SN, Lebedev AT, Shea PJ. Dynamics of PCB removal and detoxification in historically contaminated soils amended with activated carbon. Environmental Pollution. 2010; 158(3):770-7.
34. Kjellerup B, Edwards S. Application of Biofilm Covered Activated Carbon Particles as a Microbial Inoculum Delivery System for Enhanced Bioaugmentation of PCBs in Contaminated Sediment. Goucher Coll Baltimore Md; 2013.

35. Denyes MJ, Langlois VS, Rutter A, Zeeb BA. The use of biochar to reduce soil PCB bioavailability to Cucurbita pepo and Eisenia fetida. Science of the Total Environment. 2012; 437:76-82.

36. Liu X, Yu G, Han W. Granular activated carbon adsorption and microwave regeneration for the treatment of 2, 4, 5-trichlorobiphenyl in simulated soil-washing solution. Journal of hazardous materials. 2007; 147(3):746-51.

37. Liu X, Yu G. Combined effect of microwave and activated carbon on the remediation of polychlorinated biphenyl-contaminated soil. Chemosphere. 2006; 63(2):228-35.

38. Choi H Al-Abed SR, Agarwal S, Dionysiou DD. Synthesis of reactive nano-Fe/Pd bimetallic systemimpregnated activated carbon for the simultaneous adsorption and dechlorination of PCBs. Chem. Mater. 2008; 20:3649-55.

39. Das N, Basak LV, Salam JA, Abigail ME. Application of biofilms on remediation of pollutants-an overview. J Microbiol Biotechnol Res. 2012; 2:783-90.

40. Marulanda V, Bolaños G. Supercritical water oxidation of a heavily PCB-contaminated mineral transformer oil: Laboratory-scale data and economic assessment. The journal of supercritical fluids. 2010; 54(2):258-65.

41. Marrone PA, Hodes M, Smith KA, Tester JW. Salt precipitation and scale control in supercritical water oxidation-part B: commercial/full-scale applications. The Journal of Supercritical Fluids. 2004; 29(3):289-312.

42. Weber R, Yoshida S, Miwa K. PCB destruction in subcritical and supercritical water evaluation of PCDF formation and initial steps of degradation mechanisms. Environmental science \& technology. 2002; 36(8):183944.

43. Fang Z, Xu S, Butler IS, Smith RL, Koziński JA. Destruction of decachlorobiphenyl using supercritical water oxidation. Energy \& fuels. 2004; 18(5):1257-65.

44. Gedanken A. Using sonochemistry for the fabrication of nanomaterials. Ultrasonics sonochemistry. 2004; 11(2):47-55.

45. Yeow SK, Peng WL. Pretreatment for Sludge Digestion.

46. Lu JY, Du X, Lipscomb G. Cleaning membranes with focused ultrasound beams for drinking water treatment. In 2009 IEEE International Ultrasonics Symposium 2009, 1195-1198 IEEE.

47. Rodríguez JG, Lafuente A. Effective elimination of PCBs catalyzed by the palladium/hydrazine system as an ecological sustainable process. Industrial \& engineering chemistry research. 2008; 47(21):7993-6.

48. Okuno H, Yim B, Mizukoshi Y, Nagata Y, Maeda Y. Sonolytic degradation of hazardous organic compounds in aqueous solution. Ultrasonics sonochemistry. 2000; 7(4):261-4.

49. Lu Y, Weavers LK. Sonochemical desorption and destruction of 4-chlorobiphenyl from synthetic sediments. Environmental science \& technology. 2002; 36(2):232-7.

50. Chen JR, Kim D, Park JS, Gil KI, Yen TF. Reductive dechlorination of polychlorinated biphenyls (PCBs) by 
ultrasound-assisted chemical process (UACP). Environmental earth sciences. 2013; 69(3):1025-32.

51. Acar YB, Alshawabkeh AN. Principles of electrokinetic remediation. Environmental science \& technology. 1993; 27(13):2638-47.

52. Gomes HI, Dias-Ferreira C, Ribeiro AB. Electrokinetic remediation of organochlorines in soil: enhancement techniques and integration with other remediation technologies. Chemosphere. 2012; 87(10):1077-90.

53. Fan G, Cang L, Qin W, Zhou C, Gomes HI, Zhou D. Surfactants-enhanced electrokinetic transport of xanthan gum stabilized nanoPd/Fe for the remediation of PCBs contaminated soils. Separation and Purification Technology. 2013; 114:64-72.

54. Gomes HI, Dias-Ferreira C, Ottosen LM, Ribeiro AB. Electrodialytic remediation of polychlorinated biphenyls contaminated soil with iron nanoparticles and two different surfactants. Journal of colloid and interface science. 2014; 433:189-95.

55. Ottosen LM, Hansen HK, Laursen S, Villumsen A. Electrodialytic remediation of soil polluted with copper from wood preservation industry. Environmental science \& technology. 1997; 31(6):1711-5.

56. Chun CL, Payne RB, Sowers KR, May HD. Electrical stimulation of microbial PCB degradation in sediment. Water research. 2013; 47(1):141-52.

57. Naddeo V, Rizzo L, Belgiorno V. Water, wastewater and soil treatment by advanced oxidation processes (AOPs). Edizioni ASTER, 2011.

58. Nowack B. Pollution prevention and treatment using nanotechnology. Nanotechnology. 2008; 2:1-5.

59. Liou YH, Lo SL, Lin CJ, Kuan WH, Weng SC. Chemical reduction of an unbuffered nitrate solution using catalyzed and uncatalyzed nanoscale iron particles. Journal of hazardous materials. 2005; 127(1-3):102-10.

60. Clark II CJ, Rao PS, Annable MD. Degradation of perchloroethylene in cosolvent solutions by zero-valent iron. Journal of hazardous materials. 2003; 96(1):65-78.

61. Zhuang Y, Ahn S, Seyfferth AL, Masue-Slowey Y, Fendorf S, Luthy RG. Dehalogenation of polybrominated diphenyl ethers and polychlorinated biphenyl by bimetallic, impregnated, and nanoscale zerovalent iron. Environmental science \& technology. 2011; 45(11):4896903.

62. Le TT, Nguyen KH, Jeon JR, Francis AJ, Chang YS. Nano/bio treatment of polychlorinated biphenyls with evaluation of comparative toxicity. Journal of hazardous materials. 2015; 287:335-41.

63. Horváthová H, Lászlová K, Dercová K. Bioremediation vs. nanoremediation: Degradation of polychlorinated biphenyls (PCBS) using integrated remediation approaches. Water, Air, \& Soil Pollution. 2019; 230(8):204.

64. Dussert BW, Tramposch WG. Impact of support media on the biological treatment of ozonated drinking water.

65. Islam MS, Zhang Y, McPhedran KN, Liu Y, El-Din MG. Mechanistic investigation of industrial wastewater naphthenic acids removal using granular activated carbon (GAC) biofilm based processes. Science of the Total Environment. 2016; 541:238-46.

66. Ghosh U, Luthy RG, Cornelissen G, Werner D, Menzie CA. In-situ sorbent amendments: A new direction in contaminated sediment management.

67. Zimmerman JR, Ghosh U, Millward RN, Bridges TS, Luthy RG. Addition of carbon sorbents to reduce PCB and PAH bioavailability in marine sediments: Physicochemical tests. Environmental Science \& Technology. 2004; 38(20):5458-64.

68. Köhler A, Hellweg S, Escher BI, Hungerbühler K. Organic pollutant removal versus toxicity reduction in industrial wastewater treatment: The example of wastewater from fluorescent whitening agent production. Environmental science \& technology. 2006; 40(10):3395401.

69. Aktaş Ö, Çeçen F. Adsorption, desorption and bioregeneration in the treatment of 2-chlorophenol with activated carbon. Journal of Hazardous Materials. 2007; 141(3):769-77.

70. Huang X, Liu Q, Yao S, Jiang G. Recent progress in the application of nanomaterials in the analysis of emerging chemical contaminants. Analytical Methods. 2017; 9(19):2768-83.

71. Schreier CG, Reinhard M. Transformation of chlorinated organic compounds by iron and manganese powders in buffered water and in landfill leachate. Chemosphere. 1994; 29(8):1743-53.

72. Matheson LJ, Tratnyek PG. Reductive dehalogenation of chlorinated methanes by iron metal. Environmental science \& technology. 1994; 28(12):2045-53.

73. Varanasi P, Fullana A, Sidhu S. Remediation of PCB contaminated soils using iron nano-particles. Chemosphere. 2007; 66(6):1031-8.

74. Long YY, Zhang C, Du Y, Tao XQ, Shen DS. Enhanced reductive dechlorination of polychlorinated biphenylcontaminated soil by in-vessel anaerobic composting with zero-valent iron. Environmental Science and Pollution Research. 2014; 21(6):4783-92.

75. Liu J, Chen T, Qi Z, Yan J, Buekens A, Li X. Thermal desorption of PCBs from contaminated soil using nano zerovalent iron. Environmental Science and Pollution Research. 2014; 21(22):12739-46.

76. Yao Y, Miao S, Liu S, Ma LP, Sun H, Wang S. Synthesis, characterization, and adsorption properties of magnetic Fe3O4@ graphene nanocomposite. Chemical engineering journal. 2012; 184:326-32.

77. Geng Z, Lin Y, Yu X, Shen Q, Ma L, Li Z et al. Highly efficient dye adsorption and removal: a functional hybrid of reduced graphene oxide-Fe $3 \mathrm{O} 4$ nanoparticles as an easily regenerative adsorbent. Journal of Materials Chemistry. 2012; 22(8):3527-35.

78. Zeng S, Gan N, Weideman-Mera R, Cao Y, Li T, Sang W. Enrichment of polychlorinated biphenyl 28 from aqueous solutions using $\mathrm{Fe} 3 \mathrm{O} 4$ grafted graphene oxide. Chemical engineering journal. 2013; 218:108-15.

79. Gan N, Zhang J, Lin S, Long N, Li T, Cao Y. A novel magnetic graphene oxide composite absorbent for removing trace residues of polybrominated diphenyl ethers in water. Materials. 2014; 7(8):6028-44.

80. Li QL, Wang LL, Wang X, Wang ML, Zhao RS. Magnetic metal-organic nanotubes: an adsorbent for magnetic solid-phase extraction of polychlorinated biphenyls from environmental and biological samples. Journal of Chromatography A. 2016; 1449:39-47.

81. Wang M, Liu P, Wang Y, Zhou D, Ma C, Zhang D et al. Core-shell superparamagnetic Fe3O4@ $\beta-C D$ composites for host-guest adsorption of polychlorinated biphenyls (PCBs). Journal of colloid and interface science. 2015; 447:1-7.

82. Zhao RS, Liu YL, Chen XF, Yuan JP, Bai AY, Zhou JB. Preconcentration and determination of polybrominated 
diphenyl ethers in environmental water samples by solidphase microextraction with $\mathrm{Fe} 3 \mathrm{O} 4$-coated bamboo charcoal fibers prior to gas chromatography-mass spectrometry. Analytica Chimica Acta. 2013; 769:65-71.

83. Wibowo E, Rokhmat M, Rahman DY, Murniati R, Abdullah M. Batik Wastewater treatment using TiO2 nanoparticles coated on the surface of plastic sheet. Procedia engineering. 2017; 170:78-83.

84. Shaban YA, El Sayed MA, El Maradny AA, Al Farawati RK, Al Zobidi MI, Khan SU. Photocatalytic removal of polychlorinated biphenyls (PCBs) using carbon-modified titanium oxide nanoparticles. Applied Surface Science. 2016; 365:108-13.

85. Li D, Zhu J, Wang M, Bi W, Huang X, Chen DD. Extraction of trace polychlorinated biphenyls in environmental waters by well-dispersed velvet-like magnetic carbon nitride nanocomposites. Journal of Chromatography A. 2017; 1491:27-35.

86. Li J, Zhou Q, Liu Y, Lei M. Recyclable nanoscale zerovalent iron-based magnetic polydopamine coated nanomaterials for the adsorption and removal of phenanthrene and anthracene. Science and Technology of advanced MaTerialS. 2017; 18(1):3-16.

87. Wu L, Lu X, Fu X, Wu L, Liu H. Gold nanoparticles dotted reduction graphene oxide nanocomposite based electrochemical aptasensor for selective, rapid, sensitive and congener-specific PCB77 detection. Scientific reports. $2017 ; 7(1): 1-7$

88. Š evců A, El-Temsah YS, Filip J, Joner EJ, Bobčíková K, Černík M. Zero-valent iron particles for PCB degradation and an evaluation of their effects on bacteria, plants, and soil organisms. Environmental Science and Pollution Research. 2017; 24(26):21191-202.

89. Shao D, Hu J, Jiang Z, Wang X. Removal of 4, 4'dichlorinated biphenyl from aqueous solution using methyl methacrylate grafted multiwalled carbon nanotubes. Chemosphere. 2011; 82(5):751-8.

90. Shao D, Sheng G, Chen C, Wang X, Nagatsu M. Removal of polychlorinated biphenyls from aqueous solutions using $\beta$-cyclodextrin grafted multiwalled carbon nanotubes. Chemosphere. 2010; 79(7):679-85

91. Beless B, Rifai HS, Rodrigues DF. Efficacy of carbonaceous materials for sorbing polychlorinated biphenyls from aqueous solution. Environmental science \& technology. 2014; 48(17):10372-9.

92. Ren W, Chang H, Wang Y, Teng Y, Ma W, Luo Y. Effect of sulfonated graphene on uptake, translocation, and metabolism of 2, 4, 4'-trichlorobiphenyl in maize seedlings. Environmental Science and Pollution Research. 2018; 25(20):20084-96.

93. Tian J, Wei J, Zhang H, Kong Z, Zhu Y, Qin Z. Graphene oxide-functionalized dual-scale channels architecture for high-throughput removal of organic pollutants from water. Chemical Engineering Journal. 2019; 359:852-62.

94. Mahdavian L, Mousavi SE. Diameter of single-walled carbon nanotubes (SWCNTs) as an effective factor in the detection and degradation of PCBs. Polycyclic Aromatic Compounds. 2019; 39(1):14-22.

95. El-Temsah YS, Sevcu A, Bobcikova K, Cernik M, Joner EJ. DDT degradation efficiency and ecotoxicological effects of two types of nano-sized zero-valent iron (nZVI) in water and soil. Chemosphere. 2016; 144:22218 .
96. Shariat M, Raihan TM. Nano clay as an adsorbent for removes PCB from soil. Paper presented at the Conference: International Conference on Engineering and Built Environment, 2015.

97. Borji H, Ayoub GM, Al-Hindi M, Malaeb L, Hamdan HZ. Nanotechnology to remove polychlorinated biphenyls and polycyclic aromatic hydrocarbons from water: A review. Environmental Chemistry Letters, 2020, $1-8$. 